\title{
Je li Hrvatska dosegla porezni maksimum?
}

\author{
MARINA KESNER-ŠKREB Institut za javne financije
}

\section{UvoD}

Često se raspravlja treba li u Hrvatskoj dalje povećavati porezni teret uvođenjem novih poreza ili povećanjem postojećih. Proračunski deficit i javni dug sve su teže održivi, pa se izlaz najčešće traži u povećanju poreza. Političkim strukturama teže je smanjivati javne rashode nego povećati poreze, jer se porezi uglavnom odnose na brojne i prilično raspršene ekonomske subjekte. Veliki broj onih koji snose relativno mali teret poreza se teško organizira u grupe koje se mogu oduprijeti odlukama Vlade. Tako je, recimo, prilično jednostavno povećati stopu PDV-a, jer ona dotiče živote velikog broja sudionika $\mathrm{s}$ različitim interesima koji će se teško objediniti u homogenu negodujuću skupinu. S druge strane, $\mathrm{u}$ fiskalnoj prilagodbi mnogo je teže smanjivati pojedine javne rashode jer se obično zadire u prava uglavnom dobro organiziranih interesnih skupina spremnih na odlučnu borbu u očuvanju stečenih prava. Tako se, primjerice, sindikati brzo i efikasno organiziraju kada se valja suprotstaviti smanjivanju radničkih prava u javnom sektoru. No bez obzira na "lakoću" ubiranja poreza, povećanje poreznog tereta ima stanovite granice, pa se postavlja pitanje je li u Hrvatskoj ta granica već dostignuta, ili ima još prostora za daljnje povećanje porezne presije.

Odgovara se obično usporedbom udjela ukupno ubranih poreza $u$ BDP- $\mathrm{u}^{\mathrm{I}} \mathrm{u}$ gospodarski sličnim zemljama: niže oporezivanje od uspoređenih zemalja značilo bi da još ima prostora za podizanje poreza. Suprotno tome, oporezujemo li porezne obveznike više od uspoređenih zemalja, mogli bi zaključiti da poreze ne treba dalje povećavati. Ova metoda, međutim, iz više razloga može biti prilično dvojbena, pa ekonomisti pribjegavaju drugim, egzaktnijim metodama, poput mjerenja poreznog kapaciteta. U nastavku slijedi osvrt na probleme udjela poreza u BDP-u kao mjere poreznog tereta, a potom istraživanje Svjetske banke koje mjeri porezni kapacitet.

\section{UDIO POREZA U BRUTO DOMAĆEM PROIZVODU}

Hrvatski porezni teret najčešće se uspoređuje sa zemljama poreznog okruženja, tj. EU27. Ako je suditi prema visini udjela svih hrvatskih poreza u BDP-u u odnosu na prosječan udio u zemljama EU27, tada je odgovor na postavljeno pitanje pozitivan - Hrvatska bi još mogla povećati poreze. Naime, prema udjelu poreza u BDP-u (Grafikon I), Hrvatska se nalazi u zoni ispodprosječnog oporezivanja: 2OII. je udio

${ }^{\mathrm{I}} \mathrm{U}$ tekstu se podrazumijevaju porezi i doprinosi opće države. 
ukupnih poreza i doprinosa opće države u Hrvatskoj iznosio 32,9\% BDP-a, dok je prosječan udio u EU27 bio 3,5 postotna boda veći - 36,4\%.

Ipak, mnogo je uputnije - i opreznije - uspoređivati porezne terete zemalja sa sličnim BDP-om per capita, nego li s prosjekom EU27, jer on uključuje ogromne raspone: Bugarska je 2012. imala BDP-per capita 5.400 eura, dok je $u$ Luksemburgu građanin petnaest puta bogatiji i uživa u BDP-u od 80.700 eura. Hrvatski porezni teret je stoga bolje usporediti s novim državama EU-a, bližeg BDP-a per capita hrvatskome (koji je 2012. iznosio Io.30o eura), a takvi su u Poljskoj (9.900), Latviji (IO.90o), Litvi (II.Ooo), Estoniji (I3.00o), Slovačkoj (I3.200) i Češkoj (I4.600) (Eurostat, 20I4). Iz Grafikona I je vidljivo da te zemlje imaju niži porezni teret od hrvatskoga, pa bi se moglo zaključiti kako nije dobro dalje povećavati poreze, jer nama slične i konkurentne zemlje imaju porezno opterećenje čak i do šest strukturnih poena (Latvija) niže od hrvatskoga.

Dakle, usporedbom veličine hrvatskog poreznog tereta s prosjekom EU27 može se zaključiti kako bismo još mogli povećati poreze. No usporedimo li porezni teret s novim, i nama po BDP-u per capita sličnim zemljama EU-a, dolazimo do suprotnog zaključka: porezni teret ne bi trebalo više povećavati, jer nama konkurente zemlje mnogo niže oporezuju građane i poduzeća. Ovako kontradiktorni zaključci samo upozoravaju na činjenicu kako valja oprezno donositi zaključke o relativnoj veličini poreznog tereta i na temelju toga donositi brzoplete odluke ekonomske politike. No, osim opreza pri odabiru zemalja za usporedbu hrvatskog udjela poreza u BDP-u, valja upozoriti i na suštinske mane te mjere poreznog tereta.

Tako valja skrenuti pozornost na drugačiji statistički obuhvat podatka o ukupnim porezima koji služi u mjeri poreznog tereta (udjelu poreza u BDP-u) u Hrvatskoj i EU27, prikazan u Grafikonu I. Naime, u porezne podatke velike većine zemalja EU27 uključeni su iznosi naplaćenih i nenaplaćenih poreza, $t \mathrm{j}$. porezi se prikazuju prema obračunskom načelu, odnosno podaci se bilježe kada je porezna obveza nastala, bez obzira je li plaćena. S druge strane, u Hrvatskoj se porezi prikazuju prema gotovinskom načelu, pa podaci o porezima sadrže samo podatke o naplaćenim, ali ne i o nenaplaćenim porezima². Stoga bi za potpuniju usporedbu poreznog tereta s onim u EU27, hrvatske podatke trebalo povećati za iznos nenaplaćenih poreza ${ }^{3}$. Ukupni bi porezni teret tada bio mnogo veći, a prostor za novo povećanje poreza mnogo manji. Točni, ažurni i statistički provjereni podaci o ukupnim nenaplaćenim porezima i doprinosima na razini opće države, u Hrvatskoj nisu raspoloživi, no prema podacima iz Popisa poreznih dužnika koji objavljuje Porezna uprava, dugovi 84.IoI obveznika krajem siječnja 20I4. iznosili su 22 milijarde kuna. Iako nepotpun, to ipak jeste pozamašan iznos ${ }^{4}$. Kada bi se podaci o nenaplaćenima uključili u podatke o naplaćenim porezima - tek tada bi se dobili usporedivi podaci s EU27 - Hrvatska bi se, umjesto u skupini ispodprosječno oporezivanih zemalja, našla vjerojatno u skupini zemalja $s$ visokim poreznim teretom.

\footnotetext{
${ }^{2}$ Samo Bugarska, Češka, Latvija i Slovenija prikazuju poreze kao Hrvatska - po gotovinskom načelu (odnosno prikazuju samo naplaćene, ali ne i nenaplaćene poreze).

3 Vidjeti također u Bronić, 2009.

4 Izvor: PU RH, 2OI3. Uključeni su dospjeli i neplaćeni dugovi građana (veći od I5.0oo kuna), pravnih osoba (veći od 300.000 kuna) i fizičkih osoba koje obavljaju djelatnost (veći od Ioo.ooo kuna), i to na ime PDV-a, doprinosa, carina, trošarina, poreza i prireza na dohodak, poreza na dobit i promet nekretnina. Međutim, podaci ne sadrže dugove obveznika kojima je porezno tijelo odobrilo odgodu ili obročno plaćanje duga ili reprogramiranje naplate poreznog duga. Nadalje, u izračun visine duga ne uzimaju se iznosi zaduženja dospjelih u zadnja tri mjeseca prije objave popisa dospjelih i nenaplaćenih dugova. Zbog svega navedenog, podaci su nepotpuni.
} 
Grafikon I.

Udio ukupnih poreznih prihoda u BDP-u u EU27 i Hrvatskoj, 20II. godina (u\%)

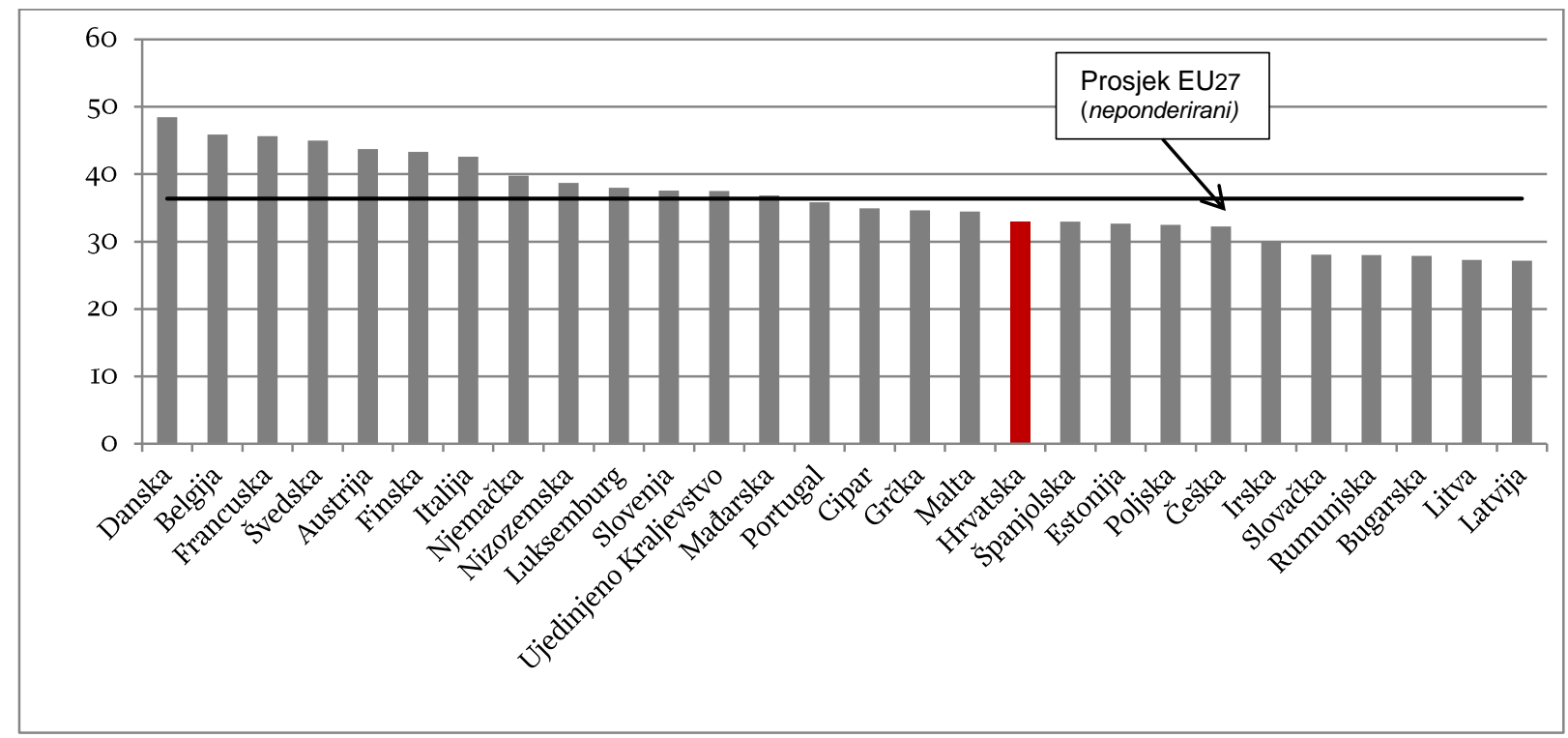

Napomena: podaci se odnose na poreze i doprinose opće konsolidirane države

Izvor: IMF (2013a i 20I3b); MFIN (20I2); DSZ (2010)

Problem je što se, uspoređujući hrvatski udio poreza u BDP-u s prosjekom zemalja EU27 ili s novim zemljama EU-a, uspoređuju statistički različiti podaci, te se na temelju toga izvlače zaključci koji mogu biti pogrešni. Samostalno korištenje udjela poreza u BDP-u kao pokazatelja poreznog tereta u međunarodnim usporedbama - bez uzimanja u obzir drugih varijabli - opravdano je ako se uspoređuju porezni prihodi zemalja slične ekonomske strukture i iste razine dohotka. No na djelotvornost ubiranja poreza, osim razine dohotka, djeluju i različiti drugi faktori kao što je ekonomska struktura, institucionalni sustav te demografski trendovi. Ti faktori određuju ono što se naziva poreznim kapacitetom neke države. Zato udio poreza u BDP-u može pružiti samo osnovnu, ali često i iskrivljenu sliku porezne djelotvornosti zemlje u prikupljanju poreza. Odnosno, udio ubranih poreza u BDP-u samo je jedan pokazatelj koji ne odražava stvarni porezni kapacitet zemlje, pa je na temelju njega nemoguće utvrditi je li zemlja u usporedbi sa sličnim zemljama dovoljno djelotvorna u ubiranju poreznih prihoda. U nastavku je prikazano istraživanje Svjetske banke (Le, Moreno-Dodson i Bayraktar, 2012) koje pokušava zaobići manjak udjela poreza u BDP-u kao mjere poreznog tereta $\mathrm{i} u$ istraživanje uključuje mjerenje poreznog kapaciteta.

\section{POREZNI KAPACITET I POREZNI NAPOR}

Kako bi se izbjegli nedostaci pokazatelja udjela poreza u BDP-u, razvijaju se dopunske metode koje osim ovog udjela uzimaju u obzir nekoliko varijabli za procjenu poreznog kapaciteta. Porezni se kapacitet obično definira kao maksimalan iznos poreza koji zemlja može ubrati u odnosu na svoja ekonomska, institucionalna i demografska ograničenja. Na taj se način dobiva vrlo koristan parametar za vođenje porezne, ali i opće makroekonomske politike.

Le, Moreno-Dodson i Bayraktar (2012), ocjenjuju porezni kapacitet na uzorku od IIo zemalja u razdoblju od 1994.-2009. i uspoređuju ga sa udjelom poreza u BDP-u. Dakle, ne promatra se samo udio poreza $u$ BDP-u kao što je obično slučaj, već se on uspoređuje s poreznim kapacitetom. Porezni kapacitet autori definiraju kao procijenjeni udio poreza ${ }^{5} \mathrm{u}$ BDP-u koji se ocjenjuje regresijskom analizom uz uključivanje specifičnih makroekonomskih, demografskih i institucionalnih osobina svake zemlje (vidjeti okvir).

${ }^{5}$ Autori su koristili podatke o udjelu poreza i doprinosa u BDP-u na razini središnje države. 


\section{Procjena poreznog kapaciteta-varijable}

U procjenu poreznog kapaciteta uključene su sljedeće varijable za koje se smatra da određuju veličinu poreza:

- BDP per capita - pozitivan i signifikantan utjecaj na ubiranje poreza, jer veći BDP per capita označava i veću poreznu osnovicu.

- Stopa ovisnosti starijeg stanovništva - negativan učinak na poreze, jer podrazumijeva niži udio produktivnog stanovništva u ukupnome i posljedično niže poreze.

- Otvorenost prema vanjskoj razmjeni - pozitivan učinak na poreze, jer otvorena gospodarstva brže rastu, pa se time širi porezna osnovica i može se ubirati više poreza.

- Udio poljoprivrednog sektora - negativan učinak na poreze, jer se podrazumijeva da visok udio poljoprivrede znači užu poreznu osnovicu.

- Kvaliteta administracije i indeks korupcije - odlučujući čimbenici koji određuju veličinu ubranih poreza.

Izvor: Le, Moreno-Dodson i Bayraktar (2012)

Nakon što se regresijski ocijeni porezni kapacitet, izračunava se indeks poreznog napora, kao omjer dijela stvarnih poreza u BDP-u i ocijenjenog poreznog kapaciteta.

- Indeks poreznog napora I označava da je udio stvarno ubranih poreza u BDP-u jednak ocijenjenom poreznom kapacitetu zemlje, što znači da se ubire točno onoliko poreza koliko dopušta porezni kapacitet.

- Indeks poreznog napora iznad I označava stanje visokog poreznog napora, što znači da je udio stvarno ubranih poreza u BDP-u veći od poreznog kapaciteta, pa nema mnogo prostora za povećanje poreza.

- Indeks poreznog napora ispod I znači da je udio stvarno ubranih poreza u BDP-u manji od poreznog kapaciteta, pa zemlja ima mogućnosti za povećanje poreznih prihoda.

Na temelju kombinacije podataka o ubiranju poreza, tj. njihova udjela u BDP-u, i indeksa poreznog napora, autori su sve promatrane zemlje razvrstali u četiri skupine (vidi Dodatak):

I. nisko porezno ubiranje, niski porezni napor;

2. visoko porezno ubiranje, visoki porezni napor;

3. nisko porezno ubiranje, visoki porezni napor; i

4. visoko porezno ubiranje, niski porezni napor.

U Tablici I. prikazana je samo druga skupina zemalja u kojoj se - u okviru zemalja u razvoju - nalazi i Hrvatska. Te zemlje bilježe udio stvarno ubranih poreza u BDP-u veći od procijenjenog poreznog kapaciteta, tako da imaju indeks poreznog napora veći od I. Prema zaključku autora, u tim zemljama više nema prostora za daljnje povećanje poreza. 
Tablica I.

Zemlje s visokim poreznim ubiranjem, visokim poreznim naporom, 1994.-2009.

\begin{tabular}{|c|c|c|c|}
\hline & $\begin{array}{l}\text { Porezi/BDP } \\
\text { (stvarni, u\%) }\end{array}$ & $\begin{array}{c}\text { Porezi/BDP } \\
\text { (procjena, u\%) }\end{array}$ & $\begin{array}{c}\text { Indeks poreznog } \\
\text { napora }\end{array}$ \\
\hline & $\mathrm{I}$ & 2 & $3=\mathrm{I} / 2$ \\
\hline \multicolumn{4}{|l|}{ Zemlje u razvoju } \\
\hline Čile & 19,34 & 19,29 & $\mathrm{I}, \mathrm{OO}$ \\
\hline Poljska & 28,42 & 27,85 & $\mathrm{I}, \mathrm{O} 2$ \\
\hline Bjelorusija & 29,89 & 28,65 & $\mathrm{I}, \mathrm{O} 4$ \\
\hline Mađarska & 35,03 & 3I,I9 & $\mathrm{I}, \mathrm{I} 2$ \\
\hline Slovenija & 34,91 & $30,8 \mathrm{I}$ & $\mathrm{I}, \mathrm{I} 3$ \\
\hline Hrvatska & 33,84 & 28,72 & $\mathbf{I , 1 8}$ \\
\hline Brazil & 20,35 & $\mathrm{I} 6, \mathrm{I} 3$ & 1,26 \\
\hline Vijetnam & $\mathrm{I} 8,46$ & $\mathrm{I} 4, \mathrm{IO}$ & $\mathrm{I}, 3 \mathrm{I}$ \\
\hline Kostarika & 22,88 & $\mathrm{I} 6,93$ & $\mathrm{I}, 35$ \\
\hline Mongolija & 20,06 & $\mathrm{I} 4,9 \mathrm{I}$ & $\mathrm{I}, 35$ \\
\hline Urugvaj & 23,85 & 17,67 & $\mathrm{I}, 35$ \\
\hline Trinidad i Tobago & 25,77 & 18,97 & $\mathrm{I}, 36$ \\
\hline Tunis & 29,05 & 19,23 & 1,36 \\
\hline Zimbabve & 23,57 & 17,36 & $\mathrm{I}, 36$ \\
\hline Novi Zeland & 30,32 & $2 \mathrm{I}, 34$ & $\mathrm{I}, 42$ \\
\hline Južnoafrička Republika & 26,56 & 18,52 & $\mathrm{I}, 43$ \\
\hline Maroko & 26,60 & 18,53 & $\mathrm{I}, 44$ \\
\hline Jamajka & 25,89 & $\mathrm{I} 7,2 \mathrm{I}$ & $\mathrm{I}, 5 \mathrm{O}$ \\
\hline Namibija & 27,53 & 17,87 & $\mathrm{I}, 54$ \\
\hline Papua Nova Gvineja & 21,56 & $\mathrm{I} 2,97$ & 1,66 \\
\hline Prosjek (neponderiran) & 26,19 & $20,4 I$ & $I, 3 I$ \\
\hline \multicolumn{4}{|l|}{ Razvijene zemlje } \\
\hline Portugal & 31,32 & 30,53 & $\mathrm{I}, \mathrm{O} 3$ \\
\hline Finska & 34,83 & 33,09 & I,O5 \\
\hline Austrija & 35,50 & 32,54 & I,O9 \\
\hline Nizozemska & 37,30 & 33,97 & $\mathrm{I}, \mathrm{IO}$ \\
\hline Ujedinjeno Kraljevstvo & 34,79 & 31,63 & $\mathrm{I}, \mathrm{IO}$ \\
\hline Norveška & $37, \mathrm{II}$ & 32,75 & $\mathrm{I}, \mathrm{I} 3$ \\
\hline Australija & 23,77 & 20,77 & $\mathrm{I}, \mathrm{I} 4$ \\
\hline Grčka & 33,00 & 28,99 & $\mathrm{I}, \mathrm{I} 4$ \\
\hline Belgija & 40,67 & 32,86 & $\mathrm{I}, 24$ \\
\hline Italija & $36, \mathrm{I} 2$ & 28,98 & $\mathrm{I}, 25$ \\
\hline Francuska & 38,77 & 30,05 & 1,29 \\
\hline Gipar & 42,50 & 30,38 & $\mathrm{I}, 4 \mathrm{O}$ \\
\hline Malta & 34,32 & 24,44 & $\mathrm{I}, 4 \mathrm{O}$ \\
\hline Prosjek (neponderiran) & 35,38 & 30,08 & I,I8 \\
\hline
\end{tabular}

Izvor: Le, Moreno-Dodson, Bayraktar (2012)

Kako je vidljivo iz Tablice I, Hrvatska je u promatranom razdoblju od 1994.-2009. imala udio stvarno ubranih poreza u BDP-u od 33,84\%. Regresijom je ocijenjen porezni kapacitet, tj. procijenjeni udio poreznih prihoda u BDP-u od $28,72 \%$, što znači da indeks poreznog napora iznosi I,I8, pa zemlja više nema prostora za uvođenje novih poreza i povećanje poreznih stopa. Za pohvalu je da Hrvatska ima indeks poreznog napora mnogo niži od prosjeka skupine zemalja u razvoju koji iznosi I,3I što znači da manje od prosjeka tih zemalja tlači svoje porezne obveznike. No, hrvatski indeks poreznog napora jednak je prosjeku skupine razvijenih zemalja $(\mathrm{I}, \mathrm{I8})$, pa je tako prema pritisku na porezne obveznike na razini razvijenih zemalja. U okviru zemalja u razvoju, sličan indeks poreznog napora kao Hrvatska imaju Mađarska i Slovenija, a u skupini razvijenih zemalja Australija, Grčka i Norveška. Ipak, bez obzira na sve, može se zaključiti da Hrvatska ubire više poreza nego što dopušta njezin porezni kapacitet.

Zanimljivo je uočiti da se od novih EU zemalja sličnog BDP-a per capita u našoj skupini zemalja - koja više nema prostora za povećanje poreza - nalazi jedino Poljska. Za razliku od Hrvatske i Poljske, Estonija, 
Latvija, Litva, Slovačka i Češka nalaze se u četvrtoj skupini koja ima niski porezni napor, pa imaju još prostora za povećanje poreza (vidjeti Dodatak).

\section{ZAKLJUČNA RAZMIŠLJANJA}

Analiza pokazuje koliko oprezno u međunarodnim usporedbama valja koristiti udio poreza u BDP-u kao mjeru poreznog tereta. Mnogo je uputnije u obzir uzeti i druge faktore koji određuju porezni kapacitet zemlje (BDP per capita, otvorenost prema vanjskoj razmjeni, udio starijeg ili poljoprivrednog stanovništva, i sl.), te tako ekonometrijski izračunati kapacitet usporediti s udjelom stvarno ubranih poreza u BDP-u. Dobiveni indeks poreznog napora će pokazati opterećuje li zemlja porezne obveznike previše ili premalo.

No još su važniji zaključci za Hrvatsku, jer je prema studiji Svjetske banke hrvatski porezni ugriz velik, pa su ubrani porezi iznad poreznog kapaciteta. Zato daljnje povećanje poreza može samo voditi do neželjenih ekonomskih poremećaja i daljnjeg narušavanja konkurentnosti zemlje. Stoga se porezne reforme ne bi smjele odnositi isključivo na povećanje poreznih stopa i uvođenje novih poreza. Prvenstveno bi cilj trebalo biti povećanje učinkovitosti ubiranja poreza, ukidanje poremećaja koje porezi uzrokuju, poboljšavanje poduzetničke klime uz osiguravanje stabilnosti poreznog sustava, pojednostavnjenje poreznih propisa i administrativnih procedura, preispitivanje porezne strukture uz prevagu onih vrsta poreza koji najmanje koče rast gospodarstva. Također je važno poboljšanje sustava upravljanja u javnim službama i smanjivanje korupcije.

Osobito valja naglasiti da se posljednji podaci u studiji Svjetske banke odnose na 2009., a hrvatske su se porezne stope nakon toga još povećavale. To se posebno odnosi na PDV koji čini oko 40\% ukupnih poreza (točnije, 36,3\% 2012.), čime je najizdašniji porezni prihod, pa promjene stopa uvelike utječu na ukupno ubrane prihode. A nakon 2009. opća stopa PDV-a porasla je s 23 na 25\%, međustopa s io na I3\%, te je ukinuta nulta stopa, što je jedan od razloga da je udio ukupnih poreza u BDP-u porastao s 32,9\% 20II. na 33,9\% 20I2. To je sve sigurno doprinijelo još nepovoljnijem indeksu poreznog napora.

Europska komisija u svojim dokumentima - posebno onima koji se objavljuju u okviru Europskog semestra $^{6}$ - također upozorava na oprez $\mathrm{u}$ daljnjem povećanju poreza u zemljama s visokim poreznim teretom. Europski semestar započinje Godišnjim izvještajem o rastu koji se objavljuje u studenom svake godine i u kojem Europska komisija navodi prioritete za sljedeću godinu koje države članice trebaju uzeti u obzir prilikom planiranja nacionale fiskalne i ekonomske politike. U Godišnjem izvještaju o rastu za 20I4. jedna od preporuka Komisije za vođenje porezne politike sljedeće godine glasi: „U zemljama s relativno visokim porezima, zdrave javne financije koje omogućavaju gospodarski rast treba osigurati smanjivanjem javnih rashoda, te proširenjem poreznih osnovica i ukidanjem pogrešno usmjerenih poreznih izuzeća, a ne povećanjem stopa” (European Commission, 2013: 6). Kako Hrvatska - kao nova članica EU-a - ove godine po prvi puta službeno ulazi u Europski semestar (ali nažalost, i u Proceduru prekomjernog proračunskog deficita), to se preporuka Komisije da ne treba dalje povećavati poreze svakako odnosi i na nju. Uostalom, i podaci studije Svjetske banke ionako ukazuju da Hrvatska ubire više poreza nego što joj porezni kapacitet dopušta, pa stoga više nema prostora za daljnji rast poreznih stopa i uvođenje novih poreza. Umjesto toga, fiskalna se konsolidacija treba usmjeriti na veću djelotvornost postojećih poreza, a još više na smanjivanje javnih rashoda.

\footnotetext{
${ }^{6}$ Europski semestar je godišnja procedura tijekom koje članice EU-a usklađuju svoje ekonomske i fiskalne ciljeve s onima dogovorenima na razini EU-a, kako bi osigurale zdrave javne financije i potakle ekonomski rast. Vidjeti više u Ott (2OI3).
} 
Porezni napor

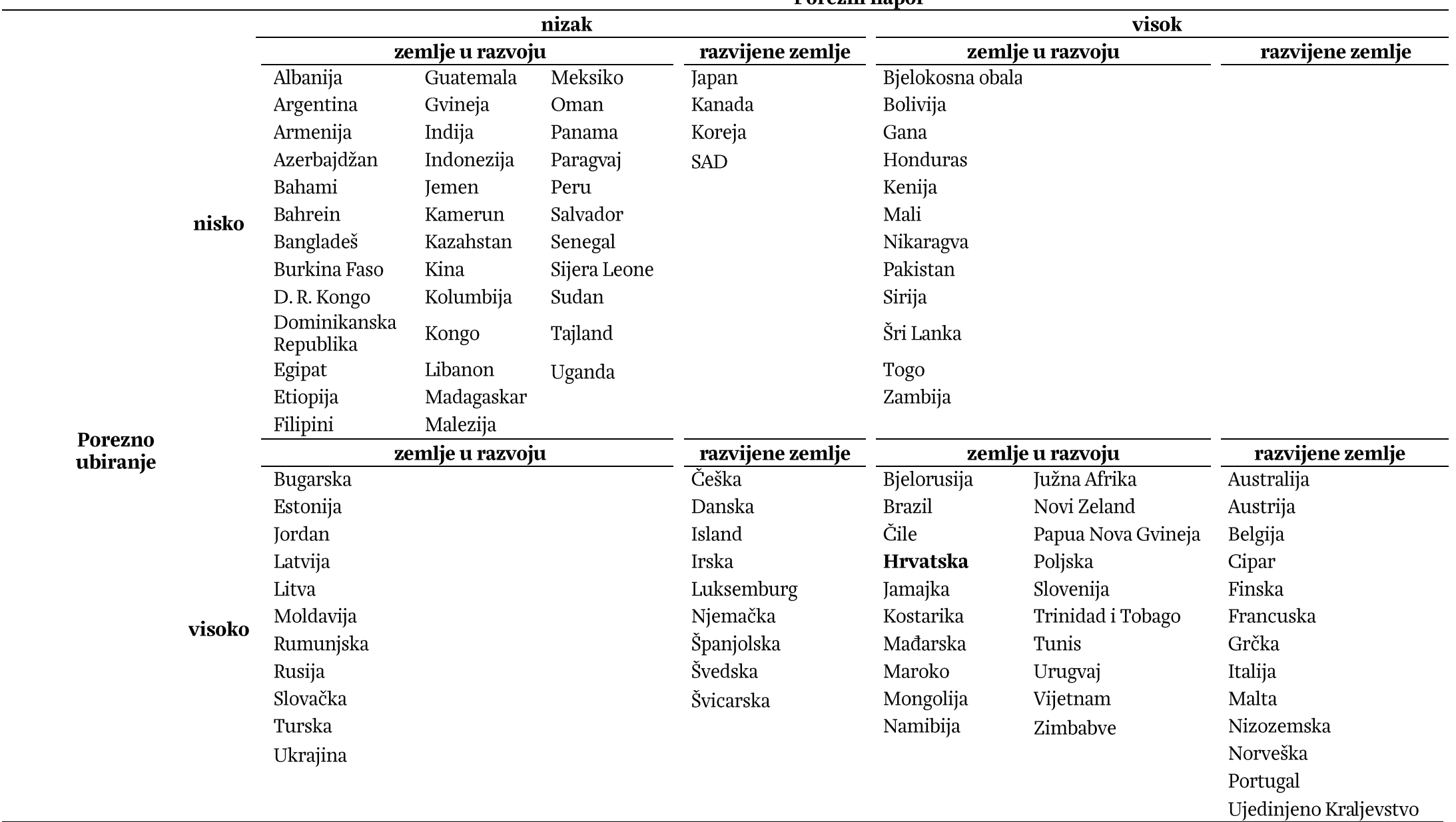

Izvor: Le, Moreno-Dodson, Bayraktar, 2012. 


\section{LITERATURA}

Bronić, M., 2009. Porezi u Hrvatskoj i u zemljama OECD-a. Aktualni osvrti, br. I6. Zagreb: Institut za javne financije.

DZS, 20Io. Revizija godišnjeg obračuna BDP-a od 1995-2007. Zagreb: Državni zavod za statistiku.

European Commission, 2013. Annual Growth Survey 2014. COM(2013) 800 final. Bruxelles: European Commission.

Eurostat, 2014. Nominalni BDP per capita 2012.

IMF, 2013a. Government Finance Statistics. Washington: International Monetary Fund.

IMF, 2013b. International Finance Statistics. Washington: International Monetary Fund.

Le, T. M., Moreno-Dodson, B. i Bayraktar, N., 2012. Tax Capacity and Tax Effort - Extended Cross-Country Analysis from 1994 to 2009. Policy Research Working Paper, WPS6252. Washington: The World Bank.

MFIN RH, 2012. Statistički prikaz, br. 212. Zagreb: Ministarstvo financija RH.

Ott, K., 20I3. Utjecaj Europskog semestra na proračunski proces u Hrvatskoj. Newsletter, br. 77. Zagreb: Institut za javne financije.

PU RH, 2013. Popis dospjelih i neplaćenih dugova. Zagreb: Porezna uprava RH. 